\title{
Improving Early Childhood Literacy by Training Parents to Utilize Digital Storytelling
}

\author{
Reza Anggriyashati Adara ${ }^{1, *}$
}

\author{
${ }^{1}$ Faculty of Communication, Literature and Language, Universitas Islam 45 Bekasi, Bekasi, Indonesia \\ *Corresponding author. Email: reza.adara@gmail.com
}

\begin{abstract}
Digital storytelling can be one of alternatives to improve early childhood literacy. This means that, literacy does not only refer to one's ability to read or write but also to a learning process. Thus, digital storytelling might not only be beneficial to teach reading and writing to younger children but also making them eager to learn more. Nevertheless, the efforts should not only be burdened to teachers. Parents should also be involved in this effort of building their children's literacy. However, in order to ensure the success, parents need to be equipped with practical approach and techniques to utilize digital storytelling to enhance their children's literacy skills. The present study is a conceptual paper which aims to suggest the effectiveness of training parents to utilize digital storytelling in order to improve their children's literacy. By involving parents, learning will not be confined to what taught at pre-school but also extended to parents-children interaction. In addition, it will strengthen bonds between parents and children.
\end{abstract}

Keywords: Literacy, digital storytelling, early childhood education

\section{INTRODUCTION}

Despite the advance of technology, the habit of storytelling is still maintained by incorporating traditional storytelling with digital technology, creating a new breed called digital storytelling. Similar to traditional storytelling, digital storytelling has been considered as beneficial to develop creativity (Ohler, 2013) and to improve learners' motivation (Smeda, Dakich, \& Sharda, 2014). Due to its benefits, digital storytelling has been incorporated to classrooms by many educational institutions (Robin, 2008). Recently, digital storytelling is integrated to early childhood education.

The idea of introducing Information and Communication Technology (ICT) to early childhood education is not a novel idea anymore. The use of digital texts and tools in early childhood education has been questioned (Burnett, 2010; Flewitt, Messer, \& Kucirkova, 2015). It is because people want to have better understanding toward the role and place of educational technologies in early childhood education contexts (Blackwell, Wartella, Lauricella, \& Robb, 2015). Thus, numerous researchers have explored the use of ICT to early childhood education. Some researchers are skeptical with it because, as claimed by Pollock, VanReken, \& Pollock, (2016), in digital era, children grow surrounded by screens and it can be disturbing for adults. However, as argued by Jenkins (2008), the debate should not centre around the effects of media to children but on what children do with media. In addition, it seems fruitless to debate why children need to stay away from technology while they are surrounded by it. Gilutz (2009) debates that these new technology developments have to be matched with the best practices and paradigms in educational psychology to support learners the most. Therefore, instead of barring children from technology, educators and researchers must find a way to get benefit of technology use for teaching children. This is why digital storytelling, as one of technological forms which can be used to teach children, seems imperative to be integrated with early childhood education.

In regards of the above idea, the present study aims to utilise digital storytelling to improve children's literacy. Firstly, it will prepare children to adapt to multiple literacies as children are required to use and adapt the changing information and communication technologies when reading and writing on the internet (Leu, Kinzer, Coiro, \& Cammack, 2004). However, children may not receive positive or informed exposure to computer interactions at home (Paciga \& Donohue, 2017). When parents know how to use technology to develop their children's literacy, their children may be more prepared to master $21^{\text {st }}$ century literacies. Besides improving children's literacy, digital storytelling allows caregivers and children to collaborate and link their stories (Pahl, 2011). As parents work together with their children to produce digital storytelling, it will help constructing their identities (Flottemesch, 2013) and creating a stronger bond by learning each other's perspectives, abilities and life experiences (Mooney \& Prins, 2015). In this regard, training parents to use digital storytelling will not only benefits their children's literacy but also strengthening their bonds as they work together to create digital stories.

The present study is a conceptual one. Thus, the discussion of present study will be limited to the suggestion of providing parents with training to utilise digital storytelling to improve children' literacy. Several studies have investigated the effects of digital storytelling to learning. 
Melwani, Tay, \& Lim (2018) used an ethnographic study to analyse a group of elementary school teachers who designed learning integrated with digital storytelling to facilitate students' literacy development and $21^{\text {st }}$ century competencies. A study of Preradovic, Lesin \& Boras (2016) showed how digital storytelling can improve children's mathematical and computer literacy skills in preschool context. Nevertheless, there is a lack of studies which specifically suggests giving training to parents for utilising digital storytelling to improve early childhood literacy, especially in the Indonesian context.

Therefore, the present study aims to fill the lack of studies which specifically discusses the benefits of digital storytelling in early childhood education as well as literacy improvement. As argued by Blackwell et al., (2015), the use of technological tools and practices in real-world childhood educational contexts need to be investigated. Such research might prevent digital divide or a condition when early childhood educators and students are not equipped with sufficient knowledge and access to effective instructions on using technology for authentic purposes (International Literacy Association, 2017). In addition, it might provide more insights on the importance of parental involvement in children's education, especially in early childhood stage.

\section{LITERATURE REVIEW}

\subsection{Digital Storytelling}

Digital storytelling can be used as one of important tools to help young children's learning. It is argued that young children develop their knowledge of surrounding world through stories they hear and participate (Semino, 2009). Similar to storytelling, digital storytelling can provide opportunities for teachers to provide meaningful learning to their students, especially young children. In this regard, digital storytelling refers to a combination of traditional storytelling with multimedia tools such as digital images, audio, video, animation and web publishing (Ohler, 2013; Robin, 2008; Robin \& Pierson, 2005). Digital storytelling might pique students' curiosities toward certain topic or provide a link from prior knowledge to new knowledge (Robin, 2006). Besides that, it is argued that digital storytelling can support students' learning by making them eager to organise and express their ideas and knowledge in an individual and meaningful way (Robin, 2008). Such activity helps students to improve their voice and talent in the child-computer interactions (Iversen \& Brodersen, 2008). In addition, digital storytelling can improve learners' literacy. It is because the stories created by learners may help them connecting meaningful content with language instruction, improving their knowledge, academic language, and literacy skills (Grabe \& Stoller, 1997). The aforementioned points suggest the importance of digital storytelling toward learning.

\subsection{The Use of Technology in Early Childhood Literacy}

There are numerous definitions of early childhood literacy depending on a particular view that one uses. Snow (2017) refers early childhood literacy to children's capacity to reciting the alphabet, naming letters, spelling simple words, recognising letters and else. Nevertheless, Pahl \& Roswell (2019) broadens the definition of early childhood literacy to children's early experiences shaped by language and engaged with multiple forms of literacies such as written scripts, oral recitation, digital media, and everyday writing. It can be said that early childhood literacy does not only cover reading or writing skills but several literacies which shaped by language around children.

There is a growing debate on the use of technology in early childhood education. The place of new technologies in early learning education is doubted because it might hinder children's imaginative play (House, 2012). In addition, integrating technology to early childhood learning is considered as far-fetched by some early learning practitioners due to lack of time and expertise to explore available hardware and software, lack of comprehension of the potential of new technologies to promote early literacies and lack of confidence to use technologies effectively (Carrington, 2005; Lankshear et al., 1996). It can be said that the use of technologies in early childhood education is still debatable.

Despite the doubts toward the use of digital technologies in early childhood education, numerous studies have shown how technology can influence early childhood literacy's development. Numerous studies have shown the integral connection of diverse digital devices to young children's early experiences of literacy (Plowman, Stephen, \& McPake, 2010; Wohlwend, 2010). In this sense, literacy refers to certain skills such as reading, writing and numeracy. In addition, it also covers the ongoing process of learning (Fransman, 2006). In regards of literacy in early childhood education, Labbo (1996) proposes a more inclusive term of literacy by including multimedia and computer-based print to refer literacy experience of younger children. According to sociocultural conceptualisations of learning, meaning making can happen through interaction using symbolic representations such as language and other cultural artefacts which have evolved over time (Wertsch, 2007). In this sense, literacy as a meaning making process can also take place through technology which acting as a cultural artefact of recent time. Besides that, children understand literacy through interaction with their environment (Goodman, 1986). As they use technology to read, write and communicate with people around them, it influences them to build a concept of what literacy is and used for. Thus, it can be said that technology can influence children's literacy.

In regards of digital storytelling, its immersion might provide ample opportunities to improve early childhood literacy. As mentioned in the previous paragraph, early childhood literacy is closely related to children's interaction and understanding of the world around them, digital 
storytelling provides a platform for children to create their own narratives either individually, or as members of small groups (Sadik, 2008), allowing them to observe and retell their experiences to the world. Furthermore, several studies suggest that digital storytelling provides instruction and knowledge developing process to improve literacy skills (Robin, 2006), media literacy (Jakes, 2006), and visual literacies (Simmons, 2006). A study of O'Byrne, Houser, Stone, \& White, (2018) on how a group of early childhood classroom found that the participants improve communication skills through organising ideas, asking questions, expressing opinions, and constructing narratives while interacting with other and computers in the creation of digital stories. Besides developing learners' technology skills, digital storytelling improves learners' motivation, facilitate integrated approached to curriculum development, and make learners engage in high thinking order (Dakich, 2008). It can be said that there is a positive connection between digital storytelling and early childhood literacy.

\section{DISCUSSIONS}

This section aims to analyse steps to train parents to utilise digital storytelling to improve early childhood literacy. This is a three-step-training; Awareness, Creation, Discussion (ACD). Firstly, parents need to know the benefits of utilising digital storytelling to improve children's literacy. This step is imperative because it will encourage them to invest time and efforts needed to produce and to discuss digital stories with their children.

Secondly, is creation. There are a lot of ways to create digital stories. In their study, O'Byrne et al., (2018) showed steps needed to create digital stories with younger children. They used a variety of digital devices such as a snowball microphone or camera to capture audio and a scanner or digital camera to capture pictures. Children will draw their story and be recorded while retelling it. After that, parents can put the drawing into scanner and use Adobe Photoshop and Premiere to digitise it. Recording can also be added after the drawing is scanned. By doing this, parents will be able to create their children's picture and audio into a digital story.

In addition to Adobe Photoshop and Premiere, parents can also use Microsoft Power point to digitise their children's story. This alternative might be more convenient than the previous one. Besides that, there are several websites which allow parents to create digital stories with their children such as Storybird, Powtoon, and Pixton. The training will provide parents with various ways they can choose to create digital stories with their children.

Lastly, parents need to discuss digital stories produced or consumed by their children. As children express their feelings and thoughts regarding digital stories, it will make parents get more involved with their children's learning. Studies demonstrate a positive correlation between parent involvement in their children's educational experiences at home (e.g., supervising and monitoring, talking about school) and children's achievement scores in reading and writing as well as grades (Griffith, 1996; Keith et al., 1998).
In addition, such discussion session can be a platform for parents to correlate digital stories consumed or produced by their children with stories happened in their family. By sharing stories, parents can introduce family values and identities as well as create bridges between generations (Flottemesch, 2013). It can be said that discussing digital stories which produced or consumed by their children have their own merits.

\section{CONCLUSION}

The present study is a conceptual paper which aims to suggest giving training to parents for utilising digital storytelling to improve early childhood literacy. Besides considered beneficial to improve children's motivation and creativity, digital storytelling can also develop early childhood literacy. However, the efforts should not only be burdened to teachers. Parents need to be involved in building their children's literacy. In order to ensure the success, training parents to utilise digital storytelling to improve their children's literacy seems imperative to be conducted. This training is needed because it might help children mastering literacies needs for $21^{\text {st }}$ century and strengthening the bonds between parents and children.

\section{REFERENCES}

Blackwell, C.K., Wartella, E., Lauricella, A.R., \& Robb, M. (2015). Technology in the lives of educators and early childhood programs: Trends in access, use and Professional Development from 2012 to 2014.

Evanston: Center on Media and Human Development at Northwestern University.

Burnett, C. (2010). Technology and literacy in early childhood educational settings: A review of research. $J$. Early Child. Lit. 10, 247-270. doi: 10.1177/ 1468798410372154.

Carrington, V. (2005). The uncanny, digital texts and literacy. Language and Education, 19(6), 467-482.

Dakich, E. (2008). Towards the social practice of digital pedagogies. In Rethinking education with ICT. Yelland, Nicola, Neal, Greg and Dakich, Eva, eds. Sense Publishers, Rotterdam, The Netherlands, pp. 13-30.

Flewitt, R., Messer, D., \& Kucirkova, N. (2015) New directions for early literacy in a digital age: the iPad. $J$. Early Child. Lit. 15, 289-310. doi: 10.1177/ 1468798414533560

Flottemesch, K. (2013). Learning through narratives: The impact of digital storytelling on intergenerational relationships. Academy of Educational Leadership Journal, 17(3), 53-60. 
Fransman, J. (2006). Understanding literacy: A concept paper. Background Paper for the Education for all Global Monitoring Report: Literacy for Life, 13(4), 230-247.

Gilutz, S. (2009). Young children's learning of novel digital interfaces: How technology experience, age, and design come into play. New York: Columbia University.

Goodman, Y. (1986). Coming to know literacy. In W. Teale \& E. Sulzby (Eds.) Emergent literacy: Writing and reading (pp.1-14). Norwood: Ablex.

Grabe, W., \& Stoller, F. (1997). Reading and vocabulary development in a second language: A case study. In J. Coady, \& T. Huckin (Eds.), Second language vocabulary acquisition (pp.98-122). Cambridge: Cambridge University Press.

Griffith, J. (1996). Relation of parental involvement, empowerment, and school traits to student academic performance. Journal of Educational Research, 90, 33 41.

House, R. (2012). The inappropriateness of ICT in early childhood education: Arguments from philosophy, pedagogy and developmental psychology. In S. Suggate and E. Reese (eds.) Contemporary debates in childhood education and development. Routledge: New York, 105-121.

International Literacy Association. (2017). Overcoming the digital divide: Four critical steps [Literacy leadership brief]. Newark: International Literacy Association.

Iversen, O. S., \& Brodersen, C. (2008). Building a BRIDGE between children and users: a socio-cultural approach to child-computer interaction. Cognition, Technology \& Work, 10(2), 83-93. doi:10.1007/s10111-007 0064-1

Jakes, D. (2006). Standards-proof your digital storytelling efforts. TechLearning. Retrieved from http://www.techlearning.com/story/showArticle.jhtml?a rticleID=180204072

Jenkins, H. (2008). Media literacy - Who needs it? In T. Willoughby \& E. Wood (Eds.), Children's Learning in a Digital World. (pp.15-39). Malden: Blackwell.

Keith, T. Z., Keith, P. B., Quirk, K. J., Sperduto, J., Santillo, S. \& Killings, S. (1998). Longitudinal effects of parent involvement on high school grades:
Similarities and differences across gender and ethnic groups. Journal of School Psychology, 36(3), 335-363.

Labbo, L. (1996). A semiotic analysis of children's symbol making in a classroom computer center. Reading Research Quarterly, 31(4), 356-385.

Lankshear, C., Bigum, C., Durrant, C., Green, B., Morgan, W., Murray, J., ...Wild, M. (1996). Literacy, technology and education: A project report. Australian Journal of Language and Literacy, 19(4), 345-59.

Leu, D. J., Kinzer, C. K., Coiro, J. L., \& Cammack, D. W. (2004). Toward a theory of new literacies emerging from the Internet and other information and communication technologies. Theoretical models and processes of reading, 5(1), 1570-1613.

Melwani, M., Tay, L. Y., \& Lim, C. P. (2018). Digital storytelling as a pedagogy to develop literacy and twenty-first century competencies in a Singapore primary school: Teachers as designers. In G. Oakley (Ed.), Mobile technologies in children's language and literacy: Innovative pedagogy in preschool and primary education (67-81). UK: Emerald Publishing Limited.

Mooney, A., \& Prins, E. (2015). Digital storytelling in family literacy programs (Practitioner's Guide No. 5). University Park, PA: Goodling Institute for Research in Family Literacy

O’Byrne, W. I., Houser, K., Stone, R., \& White, M. (2018). Digital Storytelling in Early Childhood: Student illustrations shaping social interactions. Frontiers in psychology, 9, 1800.

Ohler, J. (2013). Digital storytelling in the classroom. New media pathways to literacy, learning, and creativity (2nd ed.). Thousand Oaks, CA: Sage Publications

Paciga, K. A., \& Donohue, C. (2017). Technology and interactive media for young children: A whole child approach connecting the vision of Fred Rogers with research and practice. Latrobe: Fred Rogers Center for Early Learning and Children's Media at Saint Vincent College.

Pahl, K. (2011). My family, my story: Representing identities in time and space through digital storytelling. National Society for the Study of Education, 110(1), 17 39.

Pahl, K., \& Rowsell, J. (2019). Artifactual literacies: Every object tells a story. New York: Teachers College Press. 
Plowman, L., Stephen, C., \& McPake, J. (2010). Supporting young children's learning with technology at home and in preschool. Research Papers in Education, 25(1), 93-113. doi:10.1080/02671520802584061

Pollock, D. C., VanReken, R. E., \& Pollock, M. V. (2010). Third culture kids: The experience of growing up among worlds. London: Hachette UK.

Preradovic, M., Lesin, M. G. \& Boras, D. (2016). Introduction of digital storytelling in preschool education: A case study from Croatia. Digital Education Review, 94-105.

Robin, B. (2006). The educational uses of digital storytelling. In Society for information technology \& teacher education international conference (pp. 709716). Association for the Advancement of Computing in Education (AACE). doi: 10.1177/104345421 7697023

Robin, B. R. (2008). Digital storytelling: A powerful technology tool for the 21st century classroom. Theory into practice, 47(3), 220-228. doi: 10.1080/

00405840802153916

Robin, B., \& Pierson, M. (2005). A multilevel approach to using digital storytelling in the classroom. In Society for Information Technology \& Teacher Education International Conference (pp. 708-716). Association for the Advancement of Computing in Education (AACE)

Sadik, A. (2008). Digital storytelling: A meaningful technology-integrated approach for engaged students learning. Education Technology Res. Dev, 56, 487-506. doi: 10. 1007/s11423-008-9091-8

Semino, E. (2009). Text worlds. In G. Brone, \& J. Vandaele (Eds.), Cognitive Poetics: Goals, Gains and Gaps (pp. 33-71). (Applications off Cognitive Linguistics). Berlin: Mouton de Gruyter

Simmons, A. (2006). The Story Factor: Secrets of Influence from the art of Storytelling. New York: Basicbooks.

Smeda, N., Dakich, E., \& Sharda, N. (2013). The effectiveness of digital storytelling in the classrooms: A case study. Paper presented at the International Conference on Advanced Learning Technologies, Beijing.

Snow, C. E. (2017). Early literacy development and instruction: An overview. In The Routledge international handbook of early literacy education: A contemporary guide to literacy teaching and interventions in a global context, eds. Natalia Kucirkova, Catherine E. Snow, Vibeke Grøver, and Catherine McBride-Chang, 5-13. New York: Routledge.

Wertsch, J. V. (2007). Mediation. In H. Daniels, M. Cole and J.V. Wertsch (eds.) The cambridge companion to vygotsky. New York: Cambridge University Press, 178-192

Wohlwend, K. (2010). A is for avatar: young children in literacy 2.0 Worlds and literacy 1.0 Schools. Language Arts, 88(2), 144-152. 